\title{
A comparison of optimization models for lumber production planning
}

\author{
Comparación de modelos de optimización para la planificación de la producción de madera aserrada
}

\author{
Francisco P Vergara a*, Cristian D Palma ${ }^{\text {b }}$, Héctor Sepúlveda ${ }^{\text {a }}$ \\ *Autor de correspondencia: ${ }^{a}$ Universidad del Bío Bío, Facultad de Ingeniería, Departamento de Ingeniería en Maderas, \\ Avenida Collao 1202, Concepción, Chile, tel.: 56-41-3111668, fvergara@ubiobio.cl

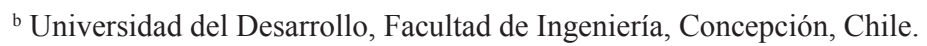

\begin{abstract}
SUMMARY
The performance of sawmills is strongly dependent on how logs are sawn into lumber in order to satisfy the customer demands. To do this, sawmill managers have to decide which cutting patterns have to be applied to logs of different dimensions. Optimization models have been proposed to assist decision makers in this process, but only the profit maximization and the cost minimization of the decisions have been considered as the models objective. In this paper, a linear optimization model was formulated to address lumber production planning and applied to a real problem. The current decisions at sawmills were compared with five different objective functions: the two previously mentioned plus waste minimization, log number minimization and production time minimization. Only profit maximization and waste minimization models reported positive economic returns. Although the current decision at sawmills also reported a positive economic return, the same economic result was obtained with significantly fewer resources using the waste minimization model. The effects of the different objectives on the production indicators were discussed.
\end{abstract}

Key words: linear programming, cutting patterns, sawmill production.

\section{RESUMEN}

El desempeño de un aserradero depende principalmente de cómo las trozas son aserradas para producir las piezas de madera demandas por los clientes. Para hacer esto, el planificador de la producción debe decidir qué patrones de corte deben ser aplicados a trozas de distintos tamaños. Los modelos de optimización han ayudado a tomar estas decisiones, pero solo se han considerado como objetivo de estos modelos la maximización de beneficios y la minimización de costos. En este artículo se formula un modelo de planificación de la producción de aserraderos, se aplica a un problema real, y se comparan las decisiones del planificador con las decisiones generadas por distintas funciones objetivo usadas en el proceso de optimización: las dos ya mencionadas además de la minimización de excedentes, minimización del número de trozas y minimización del tiempo de producción. Sólo los modelos de maximización de beneficio y minimización de excedentes mostraron retornos positivos. Aunque la solución actual del aserradero también mostró un retorno económico positivo, el mismo retorno fue obtenido con significativamente menos recursos, usando el modelo de minimización de excedentes. El efecto de diferentes funciones objetivo en los indicadores de producción es discutido.

Palabras clave: programación lineal, patrones de corte, producción en aserraderos.

\section{INTRODUCTION}

The Chilean forest sector exported almost US \$ $6 \mathrm{MM}$ in 2011, becoming the second most important economic sector after mining. The same year, lumber represented about $9 \%$ of the total exported value, with an important increase $(28 \%)$ in relation to the previous year (INFOR 2012). Although most sawmills have the latest cutting technologies that allow them to increase their productivity, focusing on the technical process itself has not been enough. They need to satisfy increasingly complex customers' demands (lumber) with limited raw material (logs). This raw material may represent up to $30 \%$ of the total production cost (Wood Markets Group Inc. 2006), which implies that even a modest improvement in the logs utili- zation rates has a major impact on the profitability of any sawmill, and therefore on the price to customers.

Sawmills transform logs of different diameters and lengths, known as log classes, into rectangular cross section lumber, of standardized thickness and width, by applying a cutting pattern to each log. Different cutting patterns could be applied to a single log class, each of them producing a number of lumber pieces of different dimensions, as well as waste material. The ratio between the amount of lumber and the amount of raw material determines what is known as the recovery factor of a cutting pattern if applied to a given log class, and is one of the most important indicators of the production performance. As log class also determines the number of lumber pieces obtained, a good combination of cutting patterns applied 
to different log classes largely affect the amount of raw material required to meet the customer demand. Based on his or her experience, the sawmill planner manages to fulfill the product demand applying the cutting patterns that have proved to be useful in the past to the best available $\log$ classes. Under real conditions, log availability seldom matches lumber requirements, leading to an increase in the waste production and poor sawmill performance. It is also a planner duty to keep high sawmill productivity and low operational costs.

Studies on efficiency have shown that many sawmills worldwide operate inefficiently. For example, using Data Envelopment Analysis (DEA) the proportion of sawmills operating efficiently in the Canadian province of British Columbia in 2002 was found to be only $7 \%$ (Salehirad and Sowlati 2005). A similar study in Norway determined that around $30 \%$ of sawmills were efficient between 1974 and 1991 (Nyrud and Baardsen 2003). Different operations research tools have been proposed to improve the performance of individual sawmills, mainly falling in one of two categories: (i) tools, mainly simulation models that estimate the amount of lumber products obtained when different cutting patterns are applied to different log classes (Pnevmaticos et al. 1974, Occeña and Tanchoco 1996), and (ii) tools, mainly mathematical programming models that help selecting the cutting patterns that optimize the process under production and resource constraints. The focus in this paper is in (ii), as in our case study the decision maker already had a set of cutting patterns with their corresponding outputs.

Different optimization models have been built to deal with the cutting pattern problem as described, and linear programming (LP) has been the most common technique (Maness and Adams 1991, Maness and Norton 2002, Todoroki and Rönnqvist 2002). Although the problem has been formulated in literature in a similar way, in some cases it has been combined with bucking decisions (Maness and Adams 1991, Maness and Norton 2002) and timber transfer decisions among plants in a supply chain context (Singer and Donoso 2007). In Todoroki and Rönnqvist (2002), a sawing optimization model is implemented in a sawing simulator hence the optimal cutting pattern is determined on a log-by-log basis; an approach that does not find the optimal log-pattern mix that best satisfies the customer demand. Multi-period models (Maness and Norton 2002, Singer and Donoso 2007, Maturana et al. 2010) have also been used with the possibility of handling inventory, of either logs or lumber, to add more flexibility. Maturana et al. (2010) compare a sawing optimization model with a heuristic that emulates the decision behavior of the sawmill scheduler. Although they omit the decision of what cutting pattern should be applied to each log class (assuming that each log is processed using its optimal cutting pattern), they showed the advantage of using the optimization model. Despite the fact that LP models have been applied to solve the production planning problems,
LP models have helped to evaluate log classes purchases and extra capacity to existing sawmills, and manage rates of consumption and production as well (Dutrow and Granskog 1986, Carino and Willis 2001).

All of the models in literature either maximize the profit or minimize the total cost of production, assuming that these are the only relevant approaches. Although these two objectives are very intuitive, the authors consider that there are other possible objectives that may better fit the managers' needs. Furthermore, lumber demand behaviors also determine the problem setting (Todoroki and Rönnqvist 2002). For instance, in presence of inelastic demand customers strongly penalize prices when facing late duedates and orders un-fulfillments; thus, cut-to-order avoiding over-under production is suggested. On the other hand, for elastic demand customers are more price tolerant with late due-dates and orders un-fulfillments; thus, cut-to-stock and over-under production does not tight the problem. Thus, the main goals of this study are to analyze and compare different sawmilling production planning approaches through alternative mathematical programming formulations. In particular, the objectives are to solve a real instance of a lumber production problem using five different objective functions -e.g. minimization of the total cost, maximization of the profit, minimization of the waste production, minimization of logs used and minimization of the processing time- and to compare the optimal solutions of these problems regarding the present solution implemented at the sawmill.

\section{METHODS}

Study case. The decision support system was developed for a medium-size sawmill located in a Southern province of Chile. The sawmill production in 2007, year used for this evaluation, was approximately $315,000 \mathrm{~m}^{3}$ of lumber that was exported to Asia, Europe and North America, and sold to the domestic market.

The model was used for planning the production to fulfill seven lumber production orders, each of them representing the demand (in $\mathrm{m}^{3}$ ) for specific dimensioned lumber pieces (details of the demand cannot be presented for confidentiality reasons). The planning period covered approximately three days of production. The sawmill had an initial inventory of 19,544 logs of different classes (totalizing $5,212.6 \mathrm{~m}^{3}$ ) to process these orders (figure 1).

Cutting patterns. To evaluate the model, 322 cutting patterns available at the sawmill database were considered. As an example, a typical cutting pattern (table 1) lists the number of lumber pieces of specific dimensions obtained by applying the pattern to different log classes. For example, cutting pattern P1 in table 1 produces four $22 \times 200$ $\mathrm{x} 4,000 \mathrm{~m} * 10^{-3}$ and four or two $23 \times 150 \times 4,000 \mathrm{~m} * 10^{-3}$ pieces depending on the log diameter. This cutting pattern can be applied to diameters 30 through $36 \mathrm{~m}^{*} 10^{-2}$, for each 


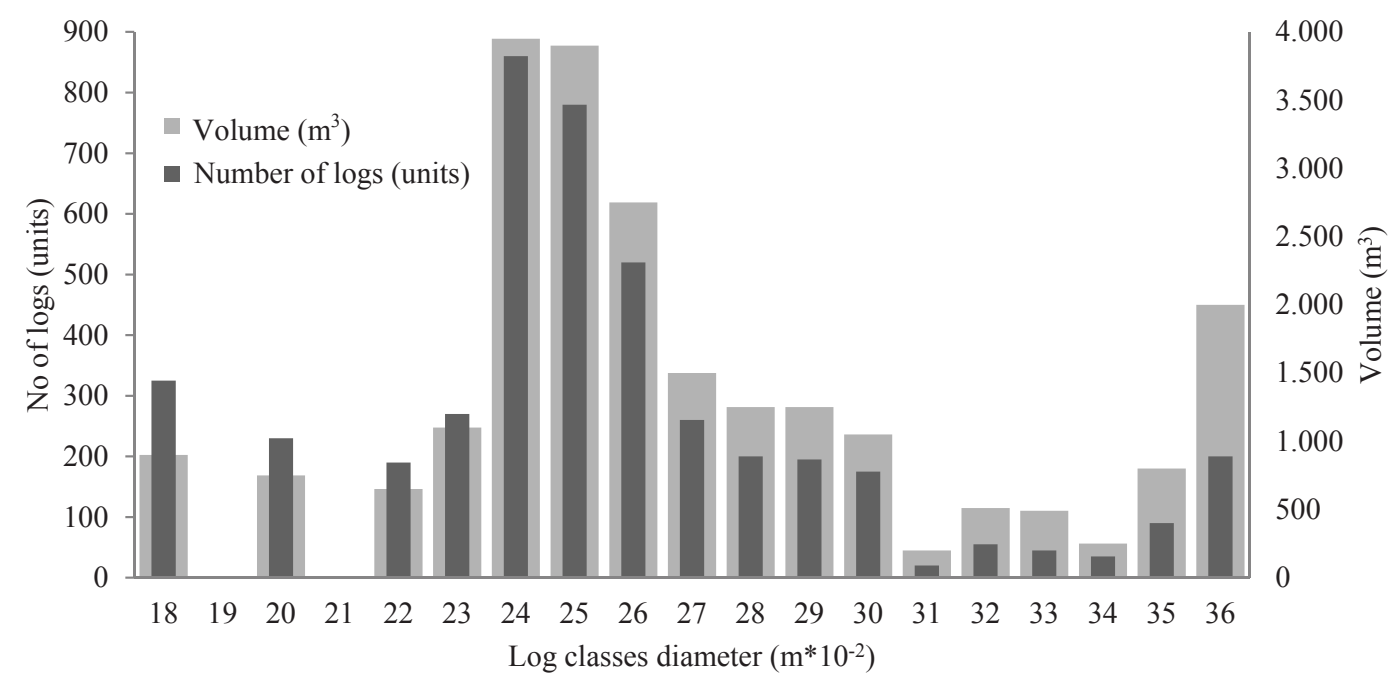

Figure 1. Logs and volume distribution of the available raw material.

Distribución del volumen y el número de trozas disponibles.

Table 1. Cutting pattern information includes the number of dimensioned lumber pieces (all for $4 \mathrm{~m} \mathrm{long}$ ) and the recovery factor by $\log$ class (size). For each cutting pattern there is a log diameter that reports its highest yield (\#).

Información de patrones de corte incluyendo el número de piezas (todas de $4 \mathrm{~m}$ de largo) y el factor de recuperación según tipo de troza (tamaño). Para cada patrón de corte hay un diámetro de trozas que reporta un máximo rendimiento (\#).

\begin{tabular}{llccccccccc}
\hline \multirow{2}{*}{ Cutting pattern } & & \multicolumn{7}{c}{ Recovery factor and number of pieces by log diameter } \\
\cline { 3 - 11 } & & 28 & 29 & 30 & 31 & 32 & 33 & 34 & 35 & 36 \\
\hline P1 & Recovery factor $(\%)$ & - & - & 52.8 & 53.5 & 53.9 & $54.1 \#$ & 54.2 & 54.0 & 53.7 \\
& $22 \times 200\left(\mathrm{~m}^{*} 10^{-3}\right)$ & - & - & 4 & 4 & 4 & 4 & 4 & 4 & 4 \\
& $23 \times 150\left(\mathrm{~m}^{*} 10^{-3}\right)$ & - & - & 2 & 2 & 2 & 4 & 4 & 4 & 4 \\
\hline P2 & Recovery factor $(\%)$ & 53.2 & 53.7 & 54.1 & $55.1 \#$ & 54.9 & 54.5 & 54.1 & 54.0 & 54.0 \\
& $23 \times 150\left(\mathrm{~m}^{*} 10^{-3}\right)$ & 4 & 4 & 4 & 6 & 6 & 6 & 6 & 6 & 6 \\
\hline P3 & Recovery factor $(\%)$ & - & 52.8 & 53.1 & $53.3 \#$ & 52.9 & 52.3 & 50.7 & 50.5 & 50.1 \\
& $23 \times 150\left(\mathrm{~m}^{*} 10^{-3}\right)$ & - & 4 & 4 & 4 & 4 & 4 & 4 & 4 & 4 \\
& $72 \times 96\left(\mathrm{~m}^{*} 10^{-3}\right)$ & - & 4 & 4 & 6 & 6 & 6 & 6 & 6 & 6 \\
\hline P4 & Recovery factor $(\%)$ & - & - & 57.9 & 58.0 & $58.2 \#$ & 57.9 & 57.3 & 57.2 & 57.0 \\
& $22 \times 200\left(\mathrm{~m}^{*} 10^{-3}\right)$ & - & - & 4 & 4 & 4 & 4 & 4 & 4 & 4 \\
& $72 \times 96\left(\mathrm{~m}^{*} 10^{-3}\right)$ & - & - & 4 & 4 & 6 & 6 & 6 & 6 & 6 \\
\hline
\end{tabular}

of which a different recovery factor is obtained. For each pattern, the log class that reports the highest recovery factor $\left(33 \mathrm{~m} * 10^{-2}\right.$ for $\left.\mathrm{P} 1\right)$ becomes the target diameter; that is, the diameter that minimizes waste production. As already explained, the demand constraints make that a cutting pattern cannot always be applied to only its target diameter, in which case an increase in the waste production is observed. A same lumber piece can be obtained by applying different cutting patterns, as is the case of a $22 \times 200 \times 4,000 \mathrm{~m} * 10^{-3}$ piece that can be obtained with P1 and P4. However, each pattern produces a different number of pieces and exhibits different lumber recovery factors.

Mathematical model. The model has to decide the number of logs of type $i$ to be processed using the cutting pattern $j$, $x_{i j}$, subject to the following set of constraints: 


$$
\begin{gathered}
\sum_{i, j} V_{i j k} x_{i j}=D_{k} \quad \forall k \\
\sum_{j} x_{i j} \leq S_{i} \quad \forall i \\
\sum_{i, j} T_{i} x_{i j} \leq H \\
x_{i j} \geq 0 \quad \forall i, j
\end{gathered}
$$

Where equation 1 ensures that the demand by a product $k, D_{k}$, is met by considering that $V_{i j k}$ is the amount of a lumber product $k$ that a cutting pattern $j$ may produce if applied to a log type $i$. This constraint was assumed as equality to fairly compare the results of the different objective functions, as some of them may suggest higher productions (e.g., profit maximization). Equation 2 limits the use of $\log$ types to their maximum availability, $S_{i}$, and equation 3 limits the total operational time ( $T_{i}$ is the time required to process a $\log$ of type $i$ ) to the maximum number of hours available to produce the orders, $H$. Equation 4 specifies the nature of the decision variables. Although the number of logs should be considered an integer number, continuous variables commonly used as solutions involve large numbers, usually thousands of logs. Using the basic model presented above, the following five objective functions were evaluated.

Cost minimization model (C_min). This objective minimizes the total cost of production. If $C_{i}$ is a combined coefficient that includes the raw material (acquisition cost per type of $\log$ ) and the operational cost (cost associated with the time spent in processing each type of log), the objective function becomes:

$$
\operatorname{Min} \sum_{i, j} C_{i} x_{i j}
$$

Profit maximization model ( $P$ max). This objective maximizes the net income coming from selling the ordered products and other by-products such as sideboard and chips, minus the total cost of production. If $P_{k}$ is the price of the product $k\left(\$ / \mathrm{m}^{3}\right), R_{l}$ and $W_{i j l}$ are the price and amount of by-product 1, respectively, and $C_{i}$ is the total cost of using a $\log$ of type $i$, as described in $\mathrm{C}_{-}$min, the following expression was maximized:

$$
\operatorname{Max} \sum_{i, j, k} V_{i j k} P_{k} x_{i j}+\sum_{i, j, l} W_{i j l} R_{l} x_{i j}-\sum_{i, j} C_{i} x_{i j}
$$

Waste minimization model (W_min). This objective minimizes the difference between the maximum recovery factor a pattern may produce, $Y_{j}^{M}$ (elements with \# in table 1), and the currently observed recovery factor, $Y_{i j}{ }^{R}$. In other words, this objective minimized the deviations of the selected patterns from their target diameters.

$$
\operatorname{Min} \sum_{i, j}\left(Y_{j}^{M}-Y_{i j}^{R}\right) x_{i j}
$$

Logs number minimization model (L_min). This objective minimizes the number of logs needed to satisfy demand orders:

$$
\operatorname{Min} \sum_{i, j} x_{i j}
$$

Production time minimization model (PT_min). This objective minimizes the number of hours needed to complete the production plan.

$$
\operatorname{Min} \sum_{i, j} T_{i} x_{i j}
$$

It should be noted that the objective of volume maximization was not considered because the demand constraint (equation 1) was defined as equality. Due to this constraint, all the models produce the same amount of lumber volume, making a volume maximization model irrelevant.

Model implementation. The successful application of decision support systems relies on both a suitable user interface and the ability to integrate data and models. Spreadsheet packages allow this integration and have emerged as one of the most popular software packages that engineers and managers use in their workplace (Eksioglu et al. 2011).

The model was implemented using Microsoft Excel, software that has a built-in programming language (VBA) that provides a complete environment to implement data analyses, generates personalized reports and builds a userfriendly interface.

To solve optimization problems, MS Excel has the Solver tool, an add-in designed to solve (very) small mathematical programming problems (200 decision variables and 100 constraints). However, the model was solved using Open Solver 1.9, an open source optimizer for Microsoft Excel that extends the Excel built-in Solver capacities and removes all limits on the problem size (Mason and Dunning 2010). Our model resulted in 25 constraints and over 5,000 decision variables.

\section{RESULTS}

The above mentioned objective functions were evaluated based on different economic and productive indicators. In this evaluation, the present decisions implemented at the sawmill (identified as Base Plan) to fulfill the production orders were also considered.

The total net profit significantly differed among the diverse objective functions (figure 2), ranging from negative 
values for the processing time, cost and log number minimization models to positive values for the other models. As expected, the profit maximization model reported the highest total profit, over $15 \%$ higher than the net profit observed with the Base Plan. The waste minimization model exhibited similar results to those obtained with the Base Plan in terms of the profit (figure 2), although using fewer resources (table 2 ).

When the profit is calculated by hour of processing time and by consumption of raw material, the waste minimization approach reported better results than those re- ported by the profit maximization approach (figure 3 ). This type of indicators is sometimes used to better monitor the sawmill performance and to anticipate situations of resources scarcity. Although lower than the waste minimization and the profit maximization approaches, the Base Plan also presented good results on this indicator. The log number, cost and processing time minimization models produced poor levels of this indicator.

All the approaches outperformed the recovery factor of the Base Plan (table 2). The profit maximization and waste minimization models increased the recovery factor in more

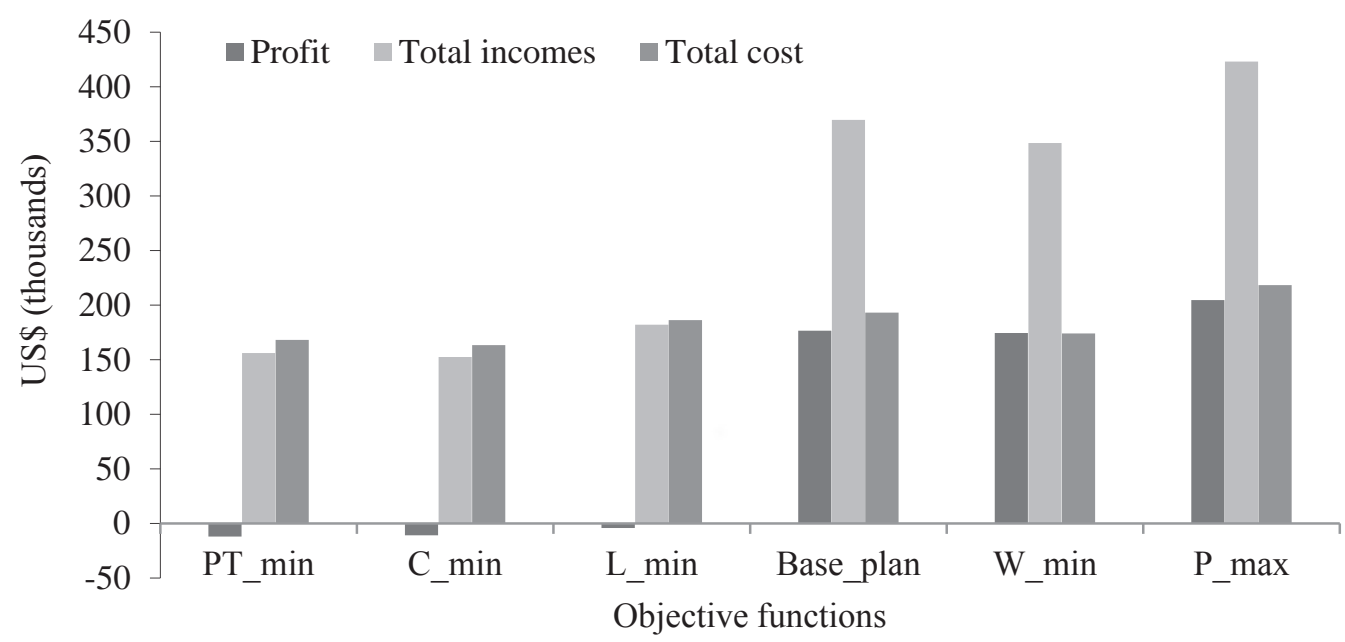

Figure 2. Cost, income and profit significantly fluctuated among the different objective function approaches.

Costo, ingreso y beneficio obtenidos difirieron significativamente entre las distintas funciones objetivo usadas.

Table 2. Recovery factor and resources used for the different approaches. The percentage of change in relation to the Base Plan is shown in parenthesis.

Factor de recuperación y recursos usados por los diferentes enfoques. El porcentaje de cambio en relación al plan base se muestra en paréntesis.

\begin{tabular}{|c|c|c|c|c|c|c|c|}
\hline Model & $\begin{array}{l}\text { Recovery } \\
\text { factor }(\%)\end{array}$ & $\begin{array}{c}\text { Production of } \\
\text { sideboards lumber }\left(\mathrm{m}^{3}\right)\end{array}$ & $\begin{array}{l}\text { Production of } \\
\text { chips (BDMT) }\end{array}$ & $\begin{array}{l}\text { Volume of raw } \\
\text { material }\left(\mathrm{m}^{3}\right)\end{array}$ & No of logs & $\begin{array}{l}\text { Raw material } \\
\text { cost (US\$) }\end{array}$ & $\begin{array}{l}\text { Production } \\
\text { time (h) }\end{array}$ \\
\hline Base Plan & 52.36 & 1,447 & 684 & 4,659 & 17,873 & 190,291 & 64.7 \\
\hline P_max & $\begin{array}{c}54.99 \\
(+5.0 \%)\end{array}$ & 1,872 & 803 & $\begin{array}{c}5,213 \\
(+11.9 \%)\end{array}$ & $\begin{array}{c}19,544 \\
(+9.3 \%)\end{array}$ & $\begin{array}{c}215,175 \\
(+13.1 \%)\end{array}$ & $\begin{array}{c}71.3 \\
(+10.2 \%)\end{array}$ \\
\hline W_min & $\begin{array}{c}54.54 \\
(+4.2 \%)\end{array}$ & 1,277 & 636 & $\begin{array}{c}4,166 \\
(-10.6 \%)\end{array}$ & $\begin{array}{c}15,612 \\
(-12.6 \%)\end{array}$ & $\begin{array}{l}171,473 \\
(-9.9 \%)\end{array}$ & $\begin{array}{c}57.0 \\
(-11.9 \%)\end{array}$ \\
\hline $\mathrm{L}_{-} \min$ & $\begin{array}{c}53.59 \\
(+2.4 \%)\end{array}$ & 1,330 & 650 & $\begin{array}{c}4,337 \\
(-6.9 \%)\end{array}$ & $\begin{array}{c}14,578 \\
(-18.4 \%)\end{array}$ & $\begin{array}{l}183,884 \\
(-3.4 \%)\end{array}$ & $\begin{array}{c}54.6 \\
(-15.6 \%)\end{array}$ \\
\hline $\mathrm{PT}_{-} \min$ & $\begin{array}{c}53.37 \\
(+1.9 \%)\end{array}$ & 1,123 & 593 & $\begin{array}{c}3,968 \\
(-14.8 \%)\end{array}$ & $\begin{array}{c}14,578 \\
(-18.4 \%)\end{array}$ & $\begin{array}{c}165,663 \\
(-12.9 \%)\end{array}$ & $\begin{array}{c}53.6 \\
(-17.2 \%)\end{array}$ \\
\hline $\mathrm{C}_{-} \min$ & $\begin{array}{c}53.27 \\
(+1.7 \%)\end{array}$ & 1,094 & 586 & $\begin{array}{c}3,918 \\
(-15.9 \%)\end{array}$ & $\begin{array}{c}15,224 \\
(-14.8 \%)\end{array}$ & $\begin{array}{c}160,837 \\
(-15.5 \%)\end{array}$ & $\begin{array}{c}55.1 \\
(-14.8 \%)\end{array}$ \\
\hline
\end{tabular}

BDMT: Bone dry metric ton of chips. 


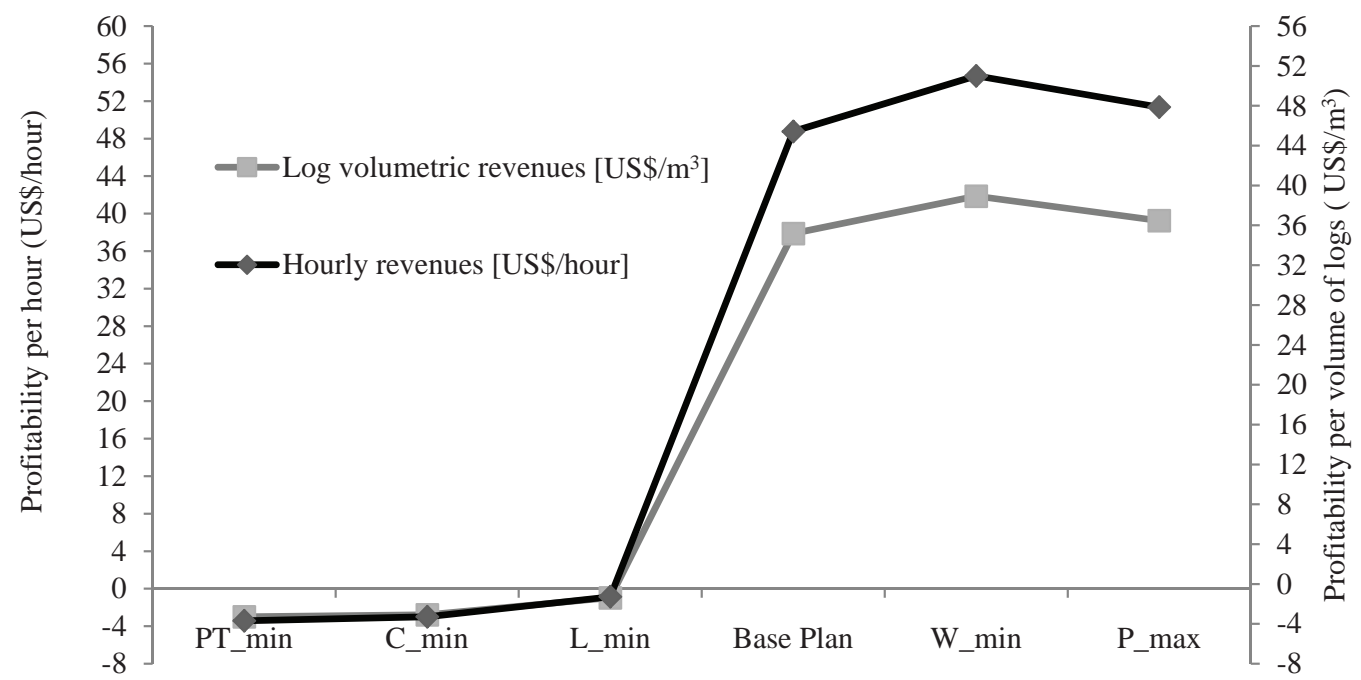

Figure 3. The Waste Minimization approach outperformed other models in terms of the profit per hour of processing time and per units of raw material used.

El modelo de minimización de excedentes fue superior a los otros modelos en términos del beneficio por hora de procesamiento y por unidad de materia prima usada.

than $4.2 \%$ in relation to the original planning. Except for the profit maximization model, all the approaches resulted in important reductions (mostly around 10 and $15 \%$ ) on both the amount and the cost of the raw material required to complete demand orders. In the waste minimization approach, for example, the demand was met using more than $2,200 \operatorname{logs}$ less than those used in the Base Plan, and savings of US\$18,818 were observed in raw material. As expected, the most important reduction in the cost of raw material occurred when minimizing the cost, although this low cost was not enough to guarantee profitability (figures 2 and 3). The latter result is explained because the cost minimization model does not consider the production of by-products. The demand for this type of products is not mandatory, but their production may represent important incomes to a sawmill.

\section{DISCUSSION}

The results and analyses of this research show that the use of different objective functions has important economic and productive implications as suggested by Todoroki and Rönnqvist (2002). These authors compared the maximization of value and volume and found significant differences in the amount of logs needed to meet demand requirements, as well as over and under sawmill production regarding lumber demand. We have also shown that the extensively used cost minimization approach does not guarantee a good economic performance. Although the existing decisions implemented at the sawmill report a positive economic return, the use of the proposed decision support system reported significant advantages over the manual planning in a similar way as described in Matu- rana et al. (2010). The waste minimization model appears as an interesting approach as it consistently reports good performance indicators.

Unlike other approaches, the profit maximization approach obtains the best economic performance at the expense of an increase in the production of by-products. However, as noted in Maturana et al. (2010), maximizing the profit is sometimes complicated in practice since the prices of products may frequently change. Furthermore, objective functions which are not able to control over production are not considered efficient (Todoroki and Rönnqvist 2002) especially in weak lumber demand conditions, and in the presence of lumber price reduction by storage time and weather exposition. The profit maximization approach not only considers the demand fulfillment when assigning the cutting patterns to logs, but also the by-products obtained. Since these products may be profitable by themselves, this approach tends to increase their production up to a point in which their contribution to the objective function becomes zero. This behavior assumes that the demand for by-products is unlimited as it happens in Chilean large vertically integrated forests companies (Epstein et al. 1999), and may represent a risky strategy when the possibility of selling them is uncertain. It should be noted that ordered products imply a formal commitment for selling a certain quantity of different products at a fixed price, while the demand for by-product is only potential and the prices used to make these decisions are usually estimated. In this sense, approaches that rely less on the by-product production may be safer in terms of the currently observed economic performance of the decisions. Although the Base Plan is less dependent on by-products than the profit maximiza- 
tion approach is, the waste minimization model generates the same economic returns producing less sideboard lumber and chips. It is due to this reduced by-product production that the later approach required significantly less raw material and production time than those required by both the Base Plan and the profit maximization model.

Although log number minimization, production time and cost resulted in higher recovery factors than the one observed in the Base Plan, their economic returns are negative, indicating that higher recovery factors do not necessarily ensure economic profit (Todoroki and Rönnqvist 2002). In general, these approaches do not take into account the production of products other than the ones explicitly modeled through the constraints. Both the profit maximization and the waste minimization approaches consider, explicitly the former and implicitly the later, the benefits of obtaining goods whose production is not constrained. In the first case, the by-products are included in the objective function, and in the second they are considered beneficial due to their contribution in reducing the production of waste. This reduced amount of waste is worthwhile as the cost of raw material is an important part of production cost (Maturana et al. 2010). In both cases, the emphasis on obtaining a good use of raw material yields the highest recovery factors. As we showed in this paper, the focus on products rather than on profit when optimizing sawing decisions has also been suggested in literature as a good approach to promote an efficient use of raw material (Todoroki and Rönnqvist 2002). As discussed, the appropriateness of one model or another depends on the specific market conditions faced by a sawmill. Recall that the models solely differ in their objective functions, the only element in which market conditions are expressed. As all models have the same constraints, changes in supply conditions are not supposed to favor certain models.

Overall, the use of a mathematical optimization tool like the one showed in this paper outperforms the personal criteria currently used in the sawmill. In addition to obtaining an optimal solution rather than a sub-optimal one as it currently occurs, two main advantages regarding its use can be identified. First, the decision making process becomes more objective as decisions obtained are free from personal criteria and bias, and are also obtained in a fraction of the time required if they were manually generated. Second, the consideration of different objective functions allows decision makers to compare all the implications that the objectives produce on the different indicators of the production process. However, the model could be improved if a multi-period framework is considered. In this case, temporal changes in the model inputs can be evaluated (Maness and Norton 2002), and orders with different completion dates could be combined in the same planning process and therefore take advantage of the variety of products that a cutting pattern can produce. In other words, a better use of the patterns diversity could be observed. Additionally, the combination of different objec- tive functions in a multi-objective setting is an interesting possibility that should be explored in future work.

Finally, for the case study and used mathematical formulation, the best use of resources, i.e. raw material and processing time, is obtained with the waste minimization approach. This approach is even better than the profit maximization approach when the profit per hour and per cubic meter is compared. These results are likely due to the reduced amount of raw material and processing time required to process the orders, while at the same time a high recovery factor is obtained. This fact is particularly important because sawmills are strongly constrained by the hours of operations. Additionally, as Chile's forest industry has depended in foreign commodity products markets (UNECE/ FAO 2002), due date and prices and orders volume are given, and must be accurately satisfied. In this scenario, the waste minimization satisfied lumber orders with $12.6 \%$ less logs volume, produced $31 \%$ less sideboard volume, and produced $21 \%$ less chips volume than those produced through profit maximization. Thus, the higher ability of this approach to control over-under production suggests that this is the most appropriate objective function to solve the production planning problem, when cut-to-order lumber is required. To our knowledge, the waste minimization approach has not been reported in literature, although its advantages over other more common approaches may be of interest to decision makers. This approach guarantees a high recovery factor and the use of fewer resources than those needed in the profit maximization approach, although it exhibits a lower profitability.

\section{CONCLUSIONS}

The main performance indicators of the lumber production process significantly vary depending on the objective function used to plan the production. Although the profit maximization approach reports the highest economic performance, it significantly increases the use of resources and the dependence of expected income in an uncertain market in relation to the other objective functions. The minimization of the costs does not guarantee a positive economic return and is translated into the lowest recovery factor among the different approaches. The waste minimization approach seems to be an interesting objective. It uses fewer resources than the ones used by the profit maximization approach and the Base Plan, therefore providing the highest revenue per unit of resource. However, a lower total economic return is obtained in comparison with the profit maximization. The minimization of logs, costs and production time reports negative profits and lower recovery factors than those reported by the profit maximization and the waste minimization approaches, although higher than results of the Base Plan. Although decisions obtained by the manual planning are reasonable good, better performance indicators and reduced solution times can be obtained using the proposed model. 


\section{ACKNOWLEDGMENTS}

The first author thanks the support of Bio Bio University, Wood Engineering Department, and Bio Bio Province, Chile, Sawmilling Industry. The second author thanks the financial support of the research project \#204607316126 granted by Universidad del Desarrollo.

\section{REFERENCES}

Carino HF, D Willis. 2001. Enhancing the profitability of a vertically integrated wood products production system: Part 2. A case Study. Forest Products Journal 51(4): 45-53.

Dutrow GF, JE Gransckog. 1973. A sawmill manager adapts to change with linear programming. Forest Services Research Paper SO. New Orleans, LA, USA. USDA Southern Forest Experiment Station. 35 p.

Eksioglu SD, M Seref, RK Ahuja, WL Winston. 2011. Developing spreadsheet-based decision support systems. Second Edition. Belmont, Massachusetts, USA. Dynamic Ideas. $956 \mathrm{p}$.

Epstein R, R Morales, J Serón, A Weintraub. 1999. Use of or systems in the Chilean forest industries. Interfaces 29(1): 7-29.

INFOR (Instituto Forestal, CL). 2012. Mercado forestal. Boletín $\mathrm{N}^{\circ}$ 48, marzo 2012. Santiago, Chile. INFOR. 12 p.

Maness T, D Adams. 1991. The combined optimization of $\log$ bucking and sawing strategies. Wood and Fiber Science 23(2): 296-314.

Maness T, SE Norton. 2002. Multiple period combined optimization approach to forest production planning. Scandinavian Journal of Forest Research 17(5): 460-471.

Mason AJ, I Dunning. 2010. OpenSolver - Open source optimization for Excel. In Ehrgott M, A Mason eds. Proceedings of the 45th Annual Conference of the Operations Research Society of New Zealand. Auckland, New Zealand. p. 181190.

Maturana S, E Pizani, J Vera. 2010. Scheduling production for a sawmill: A comparison of a mathematical model versus a heuristic. Computers \& Industrial Engineering 59(4): 667674.

Nyrud AQ, S Baardsen. 2003. Production efficiency and productivity growth in Norwegian sawmilling. 2003. Forest Science 49(1): 89-97.

Occeña LG, JMA Tanchoco. 1988. Computer graphics simulation of hardwood log sawing. Forest Products Journal 38(10): 72-76.

Pnevmaticos SM, PE Dress, FR Stocker. 1974. Log and sawing simulation through computer graphics. Forest Products Journal 24(3): 53-55.

Salehirad N, T Sowlati. 2005. Performance analysis of primary wood producers in British Columbia using data envelopment analysis. Canadian Journal of Forest Research 35(2): 285-294.

Singer M, P Donoso. 2007. Internal supply chain management in the Chilean sawmill industry. International Journal of Operations and Production Management 27(5): 524-541.

Todoroki C, M Rönnqvist. 2002. Dynamic control of timber production at a sawmill with log sawing optimization. Scandinavian Journal of Forest Research 17(1): 79-89.

UNECE/FAO (United Nations Economic Comission for Europe, $\mathrm{CH}$ - Food and Agricultural Organization of the United Nations, IT). 2002. Forest products annual market review 2001-2002. Rome, Italy. UNECE/FAO. 238 p. (Timber Bulletin - Volume LV, No. 3).

Wood Markets Group Inc. 2006. Wood markets 2006: the solid wood products outlook 2006-2010. Vancouver, BC, Canada. International Wood Market Group Inc. 567 p. 